The University of San Francisco

USF Scholarship: a digital repository @ Gleeson Library |

Geschke Center

Economics, Law, and International Business

School of Management

1995

\title{
The Evolution of First Amendment Protection for Commercial Speech
}

\author{
Karl Boedecker \\ University of San Francisco, boedecker@usfca.edu \\ Fred W. Morgan \\ Linda Berns Wright
}

Follow this and additional works at: http://repository.usfca.edu/elib

Part of the Business Law, Public Responsibility, and Ethics Commons

\section{Recommended Citation}

Karl Boedecker, Fred Morgan, and Linda Wright, Journal of Marketing. The Evolution of First Amendment Protection for Commercial Speech. Journal of Marketing, 59 (January), 38-47. 1995

This Article is brought to you for free and open access by the School of Management at USF Scholarship: a digital repository @ Gleeson Library | Geschke Center. It has been accepted for inclusion in Economics, Law, and International Business by an authorized administrator of USF Scholarship: a digital repository@Gleeson Library| Geschke Center. For more information, please contact repository@usfca.edu. 


\section{Karl A. Boedecker, Fred W. Morgan, \& Linda Berns Wright}

\section{The Evolution of First Amendment Protection for Commercial Speech}

During the past 15 years, the U.S. Supreme Court has used Central Hudson Gas v. Public Service Commission (1980) to expand significantly the power of the government at all levels to regulate advertising and other promotional activities. As a result, first amendment protection for commercial speech has steadily diminished. In this article, Supreme Court decisions subsequent to Central Hudson are reviewed to provide an update of Cohen's (1978) work. In addition, the current standard for identifying commercial speech is analyzed, and managerial recommendations are made to guide managers who are responsible for making promotional decisions in this increasingly restricted area.

$\mathbf{T}$ he U.S. Supreme Court's distinction between commercial and noncommercial speech provides for a fundamental restriction of free speech. Noncommercial speech, embodied in the phrases "freedom of speech" and "freedom of expression," is entitled to virtually full first amendment protection; ${ }^{1}$ hence, the speaker is granted considerable latitude in stating a position.

Commercial speech is generally considered to be communications that have the sale of a product or service as their ultimate goal. Content regulation of commercial speech is allowed to prevent false, deceptive, or misleading information from being transmitted (R.A.V. v. City of St. Paul 1992). In addition, the means of communications (e.g., billboards, storefront signs) can also be regulated to serve the interests of local communities (cf. Hays County Guardian v. Supple 1992; Messer v. City of Douglasville 1992).

Commercial speech was originally afforded virtually no first amendment protection. The Supreme Court reversed this position during the 1970 s, granting limited protection to commercial speech. Since 1980, the Court has once again altered the direction of first amendment decisions, resulting in additional bounds on both the content (subject matter and the explicit and imputed motives of the sender) and method (medium, timing, and location) of commercial communications. Thus, marketing's promotional component is increasingly subject to restrictions originating outside the betterknown administrative (e.g., Federal Trade Commission, Food and Drug Administration, and Federal Communications Commission) and legislative domains.

1"Fighting words" (i.e., language intended to incite violence), libel, obscene speech, and pornography are generally outside the scope of first amendment protection.

Karl A. Boedecker is a professor at the McLaren College of Business, University of San Francisco; Fred W. Morgan is a professor in the College of Business Administration, University of Oklahoma; and Linda Berns Wright is an assistant professor at the College of Business and Industry, Mississippi State University, Starkville.
The purpose of this article is to provide an analysis of the application of first amendment law to various forms of commercial expression to develop promotional guidelines for marketing managers. First, we review the evolving treatment of commercial speech under the First Amendment. In doing so, we focus primarily on changes that have occurred since Cohen's (1978) work. The current standard used by courts to identify commercial speech is then illustrated in use. Finally, the impact of commercial speech regulation on promotional decisions is discussed.

\section{The Chronology of First Amendment Decisions}

\section{2-1974: Establishing and Regulating Commercial Speech}

In Valentine v. Chrestensen (1942), the U.S. Supreme Court first declared that the Constitution placed no restraints upon government regulation of commercial advertising (See Table 1). Until this time, the Court had not distinguished between commercial and noncommercial communications and had explicitly extended first amendment coverage beyond newspapers and magazines to other media, including television, radio, billboards, pamphlets, and leaflets (Lovell v. Griffin 1938).

Subsequent to Valentine, the Court struggled inconsistently with a number of content and method issues related to commercial speech. First amendment protection was provided to door-to-door distribution of religious pamphlets (Martin v. Struthers 1943; Murdock v. Pennsylvania 1943) and to political advertising (New York Times v. Sullivan 1964). Conversely, city regulations banning door-to-door solicitation by salespeople were upheld in Breard v. Alexandria (1951), and the distribution of advertising leaflets on city streets was forbidden (Jamison v. Texas 1943). Lacking first amendment protection for commercial speech, government regulators possessed broad powers to control promotional activities by the early 1970 s. 


\section{Source}

Valentine v. Chrestensen (1942)

New York Times v. Sullivan (1964)

Bigelow v. Virginia (1975)

Virginia Pharmacy v. Citizens' (1976)

Central Hudson v. Public Service (1980)

Bolger v. Youngs Drug (1983)

Posadas v. Tourism (1986)

SFAA v. USOC (1987)

Board of Trustees v. Fox (1989)

\section{Commercial Speech Test}

Is the expression made primarily for commercial gain-the "primary purpose" test? If yes, then speech is accorded less protection.

Does the expression deal with matters that are primarily of public rather than private (e.g., financial) concern? If yes, then speech is protected.

Does the expression convey information of potential interest to a diverse audience not just to potential customers? If yes, then speech is protected.

Do potential recipients of commercial information have substantial "listener interests" served by the communications? If yes, then speech is protected?

Commercial speech referred to as "expression related solely to the economic interests of the speaker" and "speech proposing a commercial transaction." Fourpart test developed for evaluating commercial speech regulation: (1) Is the expression misleading and does it deal with lawful activities? (2) Does the government have substantial interest in the regulation? (3) Does the regulation advance the government's position? and (4) Is the regulation too extensive?

Do the various aspects of the speech combine to make the communications commercial speech?

Is the commercial activity being advertised one that could legally be banned? If yes, speech associated with the activity could also be outlawed.

Is the regulation of commercial speech no broader than necessary to advance the government's interest? [This does not require the regulation to be the "least restrictive means" possible.]

Is the regulation of commercial speech reasonable in terms of the government's asserted purpose? Again, this does not require the regulation to be the "least restrictive means" possible.

\section{5-1979: Reestablishing Protection of Commercial Speech}

The rule that commercial speech had no first amendment protection began to erode when the Court invalidated a Virginia statute that criminalized the sale or circulation of any publication that encouraged procurement of an abortion (Bigelow v. Virginia 1975). The Court stated that the government cannot restrict advertising where the commercial activity itself is legal and further noted that the "... activity advertised pertained to constitutional interests" (Bigelow 1975 , pp. 821-822).

In an ensuing case, the Court struck down another Virginia statute that had outlawed advertising of prescription drug prices. The Court stated that, "If there is a right to advertise, there is a reciprocal right to receive the advertising..." (Virginia State Board of Pharmacy v. Virginia Citizens' Consumer Council 1976, p. 757).

The Court did not, however, prohibit all regulation of commercial speech. The government could place reasonable restrictions upon the time, place, and manner of speech ${ }^{2}$ and could also enforce regulations that dealt with false, deceptive, or misleading advertising. The Court pointed out that commercial speech protection might not exist for proposed illegal transactions. It also noted that a different standard

2The "time, place, and manner" standard is applied in cases of fully protected speech. Governments can restrict when, where, and how speech is delivered, provided that the regulation does not affect the content of the speech. Such regulations are described as "content neutral." might apply for advertising in the electronic broadcast media.

Groups were permitted to openly promote their interests (trade association position) or products (contraceptives) in First National Bank of Boston v. Bellotti (1977) and Carey v. Population Services International (1977), respectively. The Court also loosened state restrictions upon advertising by professionals, most notably attorneys (Bates v. State Bar 1977; In Re Primus 1978), although a lesser degree of protection was established. In a related case, however, attorneys were prohibited from soliciting clients in person (Ohralik $v$. Ohio State Bar Association 1978). Optometrists were allowed to advertise their names but not their trade names (Friedman v. Rogers 1979).

During this same time the Court revoked a city ordinance that forbade the posting of real estate for sale and sold signs, discounting the argument that other forms of advertising were available within the community (Linmark Associates v. Township of Willingboro 1977). The Court noted that advertising alternatives such as newspapers and listings with real estate agents were more costly and did not reach prospects as readily as signs.

This period resulted in several victories for advocates of limited first amendment protection for commercial speech. Institutional advertising seemed to be acceptable as was the right to advertise in various media of the advertiser's choice. The specific content, that is, the language of advertising was not seriously examined by the Court. The Court did reserve the government's right to place reasonable restrictions on promotional efforts (Virginia State Board of Pharmacy), 
particularly if buyers were seen to be at a clear disadvantage relative to sellers (Ohralik; Friedman).

\section{0-1985: Increasing Regulation Once Again}

Five years after Bigelow, a four-part analysis for commercial speech cases was crafted in Central Hudson Gas \& Electric Corp. v. Public Service Commission (1980). The New York Public Service Commission had ordered the state electric utilities not to promote the use of electricity because of a concern that demand would exceed supply. In 1977, the Commission continued its ban but allowed institutional and informational advertising. The Court concluded that the Commission had failed to show that a more limited speech regulation would be ineffective and therefore overturned the advertising ban (Central Hudson 1980, p. 571).

As articulated in this opinion, the Court in commercial speech cases would proceed through the following steps (Central Hudson 1980, p. 566): (1) Determine whether the expression is protected by the First Amendment, that is, does it involve lawful activity and not mislead the audience? (2) Does the government have a substantial interest to be achieved by restricting the speech? (3) Does the regulation directly advance the government's interest? (4) Is the regulation more extensive than necessary to achieve that interest?

Central Hudson amounted to a significant move in the direction of regulating commercial speech, including truthful statements. The fourth step of Central Hudson has become, as will be shown, the focal point of debates in later cases. The Court's claim that this four-part test had evolved from previous commercial speech cases was not documented. Justice Blackmun, in a dissenting opinion, argued that this test allowed the Commission to manipulate the economic choices of consumers by curbing their access to information (McGowan 1990, p. 373).

In Metromedia v. San Diego (1981) the Court, using the Central Hudson test, distinguished between the advertising medium and message. The city of San Diego had barred any off-premises advertising, effectively eliminating billboard advertising; however, the rule infringed upon the general public's first amendment rights to carry or post signs carrying religious or political messages. The ordinance might have been allowed if it dealt only with commercial messages on billboards. Indeed, the Metromedia Court found that the First Amendment permits an ordinance that allows on-site advertising (storefront signs and billboards), although it forbids off-site advertising (billboards).

In In Re R.M.J. (1982) the U.S. Supreme Court supported a Missouri lawyer's contention that a state rule unduly restricted (beyond the limits established in Central Hudson) his ability to communicate with clients and prospects. The attorney had merely published an ad and mailed announcement cards describing his area of specialization.

The Court invoked Central Hudson again in Bolger v. Youngs Drug Products Corp. (1983). This dispute involved a federal statute that prohibited the mailing of unsolicited advertisements for contraceptives. Youngs's mailings included informational pamphlets describing how the use of condoms could help prevent various disorders. The last page stated that Youngs, a distributor of Trojan-brand prophylactics, had provided the pamphlet as a public service. Though Youngs prevailed, the Court broadened the permissible scope of government regulation of promotional activities by categorizing Youngs's pamphlets as commercial speech.

Central Hudson and its progeny represent a redirection in terms of deciding what degree of protection to accord commercial statements. Central Hudson amplified the Court's examination of commercial speech to include a judgment about the importance of regulating the subject matter or activity in question. The Central Hudson Court therefore withdrew some of the protection bestowed upon commercial speech during the previous five years.

\section{6-1992: Extending Regulation Even Further}

The Court greatly expanded governmental powers to control promotional activity in Posadas de Puerto Rico Associates $v$. Tourism Company of Puerto Rico (1986). The Puerto Rican legislature had legalized casino gambling but prohibited the casinos from promoting their facilities to Puerto Rican citizens. The Tourism Company, established by the legislature, administered the gaming industry. That agency prohibited casino franchise holders from using the word casino on any items accessible to people living in Puerto Rico. Posadas, a casino holding company, was fined for violating these regulations and subsequently challenged them.

Reacting to Posadas's objection, the Puerto Rico Superior Court rewrote the regulations to try to resolve the first amendment problems. The revised standards relaxed some of the regulatory agency's restrictions, but nonetheless allowed use of the word casino only where the trade name of the hotel was used. The standards also required previous approval of the Tourism Company for advertising and publicity addressed to tourists within Puerto Rico.

The Court declared that advertising of casino gambling could be forestalled because casino gambling itself could be banned. So where the underlying commercial endeavor could be outlawed, the government can forbid promotional activities regarding the endeavor. Thus, Posadas substantially reduced first amendment support for commercial communications by upholding government authority for both previous restraint and censorship of truthful advertising for a legal service.

The regulatory expansion of Posadas continued in San Francisco Arts \& Athletics, Inc. v. United States Olympic Committee (1987) (SFAA v. USOC). The USOC had been granted exclusive use of the word Olympic by the Amateur Sports Act of 1978. Without USOC's permission, SFAA had begun using the term in promotional materials to create interest in the proposed Gay Olympic Games. The USOC obtained a permanent injunction, preventing SFAA from using the word Olympic in any of its activities, ${ }^{3}$ and SFAA appealed.

In finding for the USOC, the Court stated that the "possibility for confusion as to sponsorship is obvious" (SFAA $v$.

3The Amateur Sports Act (1978) provides the USOC with broader control over the word Olympic than would be available for a trademark under the Lanham Act (1988). The USOC can prohibit the use of the word even in situations where there is no evidence of consumer/viewer confusion. 
USOC 1987, p. 2982). The SFAA had intended both commercial and noncommercial use of the word, including the sale of several items carrying the Gay Olympic Games slogan. The SFAA argued that the games would promote greater understanding among people of different ages, races, and sexual preferences. Thus, by banning the use of the word Olympic, the Court effectively blocked a considerable amount of noncommercial speech as well.

Justice Brennan objected strongly to the $S F A A$ decision. He maintained that the Amateur Sports Act restricts commercial speech beyond that required to further a substantial government interest-an outcome incompatible with the fourth step of the Central Hudson test. ${ }^{4}$ The SFAA essentially condones the arbitrary suppression of nondeceptive uses of the word Olympic. To protect the USOC's rights, the Court might have granted USOC a trademark for the word Olympic and required users of the word to include a conspicuous disclosure statement (Garrison 1991).

The Court next reviewed a case involving an attorney soliciting prospects by letter (Shapero v. Kentucky Bar Association 1988) in violation of a rule prohibiting direct mail solicitation for pecuniary gain. The Kentucky Supreme Court upheld this law, even though the letter was found not to be false or misleading by any reviewing body.

The Court found for the attorney, stating that the First Amendment does not permit a complete ban on some forms of commercial speech simply because they are more effective than other methods. The Court also decided that eliminating such communications would be inconsistent with Posadas, ${ }^{5}$ although such a letter could result in isolated abuses, that is, mislead some people. The Court concluded that direct mail advertising is dissimilar to personal solicitation because the latter provides many more opportunities for undue seller influence. Direct mail, because it leaves a tangible record, is also more open to public scrutiny and proper regulation by authorities than is personal selling. Thus, whereas the Court allowed direct mail selling, it introduced reasoning that eventually could be used to regulate face-toface selling under the First Amendment.

The Court reaffirmed government power to ban promotional activities in Board of Trustees of the State University of New York v. Fox (1989). The trustees had issued regulations that prohibited certain commercial activities on any university property. Fox, a student hosting product demonstration parties in dormitories, contested the regulations. The trial court upheld the trustees's regulations, which were overturned on appeal.

The U.S. Supreme Court reversed the appellate judgment and remanded the case for consideration of whether the regulations were adequate under the fourth step of Central Hudson. The Court opined, however, that demonstration

\footnotetext{
${ }^{4}$ Regarding the impact on noncommercial speech, he noted that USOC has permitted the word Olympic to be used in reference to young persons (Junior Olympics and Explorer Olympics) and handicapped people (Special Olympics), while disallowing its use in reference to senior citizens and bodybuilders (SFAA v. USOC 1987, p. 2999). He asserted that restrictions such as these amount to arbitrary content regulation of speech, which is completely at odds with first amendment prohibition of restrictions that are not content neutral.

${ }^{5}$ Because the practice of law cannot be banned, attorney advertising must therefore be lawful.
}

parties amounted to commercial speech that proposed a lawful transaction and was not misleading. The Court thereby upheld the power of a government body to prohibit the nondeceptive selling of legal products in an individual's residence. Fox noticeably extended the reach of the fourth element of the Central Hudson test from "no more extensive than necessary" to the "reasonableness" of the regulation in the context of its objectives. The Fox Court explicitly noted that it will not apply a "least restrictive means possible" analysis to commercial speech.

Then, in Peel v. Attorney Registration and Disciplinary Commission of Illinois (1990), the Court negated an Illinois rule prohibiting attorney claims of being a certified legal specialist. The Court found Peel's letterhead to be truthful, not misleading, and verifiable and therefore nondeceptive. The Court conceded that a state does have a right to prevent deception that might arise out of communications such as Peel's, but this interest was deemed insufficient to justify a categorical ban.

\section{3: Refining the Central Hudson Standard}

The Supreme Court applied the Central Hudson standard in three 1993 commercial speech cases, probably causing more confusion than clarification. In City of Cincinnati v. Discovery Network (1993) and Edenfield v. Fane (1993), the Court rejected a city ordinance prohibiting magazine and handbill news racks (while allowing newspaper racks) and overturned a Florida statute preventing accountants from soliciting clients in person and by phone, respectively. Although they met the first two prongs of the Central Hudson, both these rules failed the third prong, that is, neither standard directly advanced either governmental unit's asserted interests. Both governments could have achieved their interest in other ways that did not unreasonably restrict commercial speech.

Conversely, the Court upheld a federal law prohibiting radio stations from broadcasting lottery ads in states where lotteries are forbidden (US and FCC v. Edge Broadcasting Co. 1993). A radio station in North Carolina (which has no lottery), with $92 \%$ of its listeners living in Virginia (which has a lottery), challenged the federal statute. The Court accepted the state's argument without relying on any demonstrable evidence, contrary to Edenfield.

Taken together, Edenfield and City of Cincinnati require the government to support its position more thoroughly when banning certain forms of commercial speech. Edge Broadcasting, however, relaxes the evidentiary requirements for the state. Moreover, the Court has yet to clarify the term reasonable 6 when applied to a law regulating commercial speech.

\footnotetext{
${ }^{6}$ Although the Court now seems to require the state to show through extrinsic evidence that a statute is reasonable, it has yet to offer a useful definition of the word reasonable. See Mandel (1994) for a discussion of this issue and a review of the 1993 Supreme Court commercial speech cases.
} 


\section{4: Limited Developments}

In Ibanez $v$. Florida (1994) the Court discussed commercial speech issues. ${ }^{7}$ Here, the Court rejected a Florida Board of Accountancy ruling that sought to prevent Ibanez from displaying her Certified Financial Planner credential on her business cards, stationery, and Yellow Pages listing next to her CPA and JD designations. This decision is compatible with earlier rulings allowing professionals to advertise and recognizes the legitimacy of promoting professional organization memberships other than state-sponsored ones.

\section{Summary of Commercial Speech Cases}

The U.S. Supreme Court continues to refine the distinction between speech proposing commercial transactions and other varieties of speech. More types of communication (in terms of topics) tend to be moving to the commercial speech category, thus further eroding overall first amendment protection for commercial expression. As a result, marketers face a two-tiered dilemma (identifying commercial speech and applying the current commercial speech standard) when trying to gauge the border between allowable and impermissible communications.

\section{Working With the Current Commercial Speech Standard}

Marketers who are developing communications programs must therefore address two fundamental issues regarding the First Amendment. The initial concern is to develop a sense of the Court's current operating definition of commercial speech. The second issue relates to the Court's view of commercial speech content and method of communication in the context of Posadas and ensuing opinions.

\section{Identifying Commercial Speech}

The most elementary issue in a commercial speech case is whether the communication is in fact commercial and therefore should receive a lesser degree of protection (Petty 1993). The commercial/noncommercial distinction has been criticized routinely since its inception (cf. Murdock v. Pennsylvania 1943; Thomas v. Collins 1945). The essential problem is definitional: Criteria for identifying commercial speech are not precise and have improved very little since Valentine.

Most product-specific communications typify so-called pure commercial speech. Product-line, product-family, and some forms of corporate image advertising would also be categorized as commercial speech. Thus, the majority of promotional efforts would seem to be properly classified as commercial speech. Gradation problems arise, however, when (1) the speaker is not a for-profit entity and/or is presumably neutral regarding the subject matter, or (2) the content of the speech includes topics that traditionally are both commercial and noncommercial. Such speech is labeled mixed and may be fully protected because of its noncom-

\footnotetext{
${ }^{7}$ City of Ladue v. Gilleo (1994) also includes some comments about commercial speech.
}

mercial aspects or treated subordinately due to its commercial component.

Not-for-profit or neutral speakers. Many organizations that are legally organized as nonprofit institutions carry out fund-raising activities with full first amendment protection, except in cases of fraud. ${ }^{8}$ The most obvious examples are religious, political, and charitable groups. ${ }^{9}$ Consider billboards sponsored by an organization that feature a renowned evangelist. Suppose the message urges viewers to purchase expensive religious icons so as to be viewed more favorably by the deity worshiped by the evangelist. The religious nature of the source gives it first amendment protection despite the fund-raising nature of the communications.

Another relevant example for marketers relates to dealing with consumer interest groups or consumer watchdogs. These groups and individuals are generally allowed greater leeway in stating their positions about products than are the companies marketing these items. The Court's premise is that these sources of information do not stand to gain financially from their comments; hence, their positions are presumed to be neutral or more plausible than profit-oriented marketers. Thus, marketers encounter credibility problems when trying to negate the opinions (noncommercial speech) of presumably neutral sources, such as Consumer Reports (Redish 1990, p. 49), with their own commercial statements.

Evaluating profit motives will be increasingly difficult to assess as complex business structures, such as strategic alliances, emerge. For example, several competing firms may establish a not-for-profit joint venture to obtain research economies of scale. The affiliated firms benefit if this research venture proclaims that the most advanced technology in a given area just happens to be that of the funding companies. The not-for-profit partnership is the source of the statement, but for-profit companies have underwritten the research. The Court is likely to view such statements as commercial speech, unless it is convinced that the joint venture is remote enough from its sponsors, that is, no common personnel, physically separate facilities, and minimal sponsor control over the research agenda.

Commercial/noncommercial topics. Health-related information is widely available in the U.S., 10 although food and drug marketers have long been battling federal agencies for greater freedom to advertise the health benefits of their offerings (Calfee and Pappalardo 1991). However, communications about the health-related impact of products are controversial relative to the First Amendment. For example, Retin-A has recently been observed to lighten liver spots, a

\footnotetext{
${ }^{8}$ Commercial speech that is acceptable under the First Amendment is not protected if it leads to statutory violations (cf. ES Development v. RWM Enterprises 1991).

9See, for example, Cantwell v. Connecticut (1940) and Gaudiya Vaishnava Society v. San Francisco (1991)-religion; Boos v. Barry (1988)politics; Schneider v. State (1939)-charity. For a discussion of these primary first amendment topics, see Caywood and Preston (1989) or Estlund (1990).

10The federal government assembles health information for international travelers (Wade 1992), and cable television networks provide several channels that concentrate on health-related topics (Husni 1991). At the same time, food marketers claim that consumers are demanding more health-related information (Dowdell and Crispens 1991).
} 
TABLE 2

Issues of Concern in an Analysis of Commercial Expression

Issue

Message sender

Message receiver

Message content

Medium

Government's role

in protecting:

Sender

Receiver

Public

\section{Concerns of the Court}

Right to communicate with target markets or the general public

Right to receive information about products/choices; right to ignore information; right not to be "exposed too aggressively" to information

Information versus persuasion; product information versus corporate image information versus general information; social importance

Intrusiveness; pervasiveness; alternative media (availability and cost effectiveness)

\section{Reasonable access to media}

Balancing knowledge between sender and receiver; balancing power between sender and receiver

Minimum, established standards; avoiding unwarranted intrusions; restricted, sensitive topics

finding reported by the same research team at the University of Michigan that four years earlier discovered that RetinA smooths facial wrinkles (Waldholz 1992). This research project was funded in part by Johnson \& Johnson (J\&J), which manufactures and markets the drug and arguably benefits from these findings.

Given the same study and findings, Michigan would be given greater freedom to state its position than $\mathrm{J} \& \mathrm{~J}$, because the university's research is not done for the purpose of eventually marketing profitable products. If $\mathrm{J} \& \mathrm{~J}$ mailed results of this research to health professionals, its communications would come under Food \& Drug Administration examination, which would be more restrictive than a first amendment review. A J\&J-sponsored press conference, because it involves disseminating information to the public through the news media, would be subject to greater scrutiny under first amendment guidelines. Full-page advertisements by J\&J in magazines and newspapers, even if they described only the benefits of Retin-A, would likely be deemed commercial speech. ${ }^{11}$ Even if this is commercial speech, some analysts argue that the public interest component deserves full first amendment protection (Radner 1993).

Summary of the identification problem. None of the standards forwarded in New York Times (1964), Bigelow (1975), and Virginia Pharmacy (1976), the major commercial speech cases preceding Central Hudson (1980) (see Table $1)$, truly clarifies the commercial speech conundrum. Thus, the threshold decision of whether certain communications amount to commercial speech can sometimes be a difficult one for the Court.

11 Advocacy advertising is being increasingly scrutinized by the FTC. On balance, the FTC's approach and the recommendations of commentators (cf. Cutler and Muehling 1989, 1991; Middleton 1991) are very similar to the type of analysis conducted in first amendment challenges.

The R.J. Reynolds "Of Cigarettes and Science" advertorial is another example of complex, competing positions. The FTC alleged that the ad misrepresented the health risks related to smoking, and R.J. Reynolds consented to cease the ad (In Re R.J. Reynolds 1990).

Commentators have been particularly critical of the Nutrition Labeling and Education Act (1990), suggesting that it violates the First Amendment (Blim 1994).
The Court initially influences the outcome of a dispute by categorizing the controversial speech as noncommercial and thereby virtually impossible to silence. Firms attempt to sway the Court in this direction by cloaking their commercial messages with controversial or noncommercial subject matter. However, the tendency seems to be to classify more and more types of mixed speech as commercial speech, which is then judged according to Central Hudson, Posadas, and subsequent litigation.

\section{Applying the Current Standard}

After determining that the speech in question is commercial, the Court must examine the content and method of the speech in the context of the conflicting rights and interests involved (Collins and Skover 1993a, b; Kozinski and Banner 1993; Smolla 1993). A listing of the primary issues/interests that must be considered by the Court is presented in Table 2 , along with a brief description of each.

The Court obviously will have a difficult time ensuring that all interests are maximized because of the inherent trade-offs involved. The right of a marketer to target advertisements to certain market segments might interfere with rights of those not wanting to see the ad or not wanting third parties to view the ads (Nesgos 1988). For example, for a variety of reasons some people may be offended by ads for contraceptives. Their inadvertent exposure to such ads is regarded as less important than the right of others to be informed about contraceptive alternatives and the right of contraceptive sellers to promote their products. Moreover, given broad public concern for minimizing the spread of AIDS, the recognized utility of contraceptive use has increased. However, if the ads are offensive in their execution, for example, vivid photography and colorful language, the Court may decide to protect society at large from such materials.

Thus, the Court must balance the various rights in the context of existing trends and societal values. If a cure for AIDS is developed and is eventually affordable to everyone, the rights of those objecting to contraceptive ads may begin to dominate again, resulting in restrictions on contraceptive advertisements. At that point, such ads may be prohibited from all broadcast media but might be permitted in an infor- 
mational format in print media targeted primarily at adults. The rights of the contraceptive seller would become secondary and would therefore be constrained but not eliminated.

A recent appellate decision involving the Adolph Coors Co. also illustrates the problems of separating intertwined rights (Adolph Coors Company v. Bentsen 1993). Coors sought permission to disclose the alcoholic content of two of its products on labels and in advertisements. Regulations of the Bureau of Alcohol, Tobacco, and Firearms, dating back to 1935 , forbid such disclosures. Coors convinced the trial court to enjoin the enforcement of this regulation. The appellate court (10th Circuit) agreed, stating that the regulation failed the third and fourth prongs of the Central Hudson test. Coors's right to advertise, the public's interest in disclosures, and the government's asserted interest in preventing alcohol strength wars among brewers are in conflict and must be harmonized.

Other situations may encompass only the rights of the parties directly involved in the dispute. For example, when states attempt to establish behavioral standards for professionals, for example, optometrists, physicians, and attorneys, they risk first amendment violations. After Edenfield (1993) accountants are allowed to approach potential clients in person or by telephone, but attorneys are not yet permitted to solicit this aggressively. The Court must determine how to protect exposed citizens who need legal counsel but who might be susceptible to persuasive legal arguments, while at the same time safeguarding the right of others (attorneys) to communicate with prospective clients.

The rationale of Central Hudson, which was extended considerably in Posadas, will be used to decide issues such as these. Assuming the commercial communications are lawful and not misleading (Central Hudson, step \#1), the weight attached to governmental interest in regulating the questionable communications must be judged (step \#2). Rarely will a regulation be expunged at this stage. The logic underlying the contested rule will almost always be reasonable in terms of face validity, and the governmental body's articulated reasons for enacting the statute will usually be well intended. Step \#3 will also typically result in an affirmative answer: Most regulations advance the government's interests. In fact, the legislative process at all levels generally includes an analysis of the congruence between the government's goals and the functioning of the law.

Most important, the appropriateness of the commercial speech restrictions is finally evaluated by the Court. The test is whether the restrictions are reasonable or no more extensive than necessary not whether they are the least restrictive means possible. Thus, the Court must review arguments regarding alternative promotional formats and message content available to the marketer.

\section{Impact of Commercial Speech Regulations on Promotional Decisions}

At the present time, targeted promotional efforts aimed at informing interested and qualified prospects and customers re- ceive the maximum commercial speech protection. Communications of demonstrable claims are generally also acceptable to the Court. This protection is decreased somewhat for highly persuasive efforts, especially if the seller is clearly more familiar with the product than buyers. Untargeted mass communications that attempt to do more than inform and that cannot be avoided by uninterested persons are closely scrutinized by the Court.

Like marketers, the Court considers the impact of the commercial speech and its medium of delivery in applying Central Hudson. In reviewing statutes designed to control promotional alternatives, the Court has most often been critical of absolute bans because they are overly broad, thus failing the fourth step of Central Hudson; that is, statutes must not only effectively prevent unwanted commercial speech through media restrictions, but they must not impinge upon allowable noncommercial speech.

Attempts to regulate media have very consistently focused on the particular advantages of those media from the marketer's perspective. The Court has learned that a particular message is more effective when transmitted by one medium as opposed to another. The promotional activities most likely to be affected by commercial speech regulations are outdoor advertising, direct marketing, personal selling, and television advertising.

\section{Outdoor Advertising}

Numerous statutes have been enacted to limit or eliminate billboards and signs. Decisions dealing with these regulations often note that billboards and signs are publicly intrusive: They cannot be ignored or avoided due to their physical presence. The Court has issued enough opinions to date that could be used to draft legislation calling for the banishment of all commercial signs and billboards that are not within a few hundred feet of the establishment being advertised. ${ }^{12}$ Firms large enough to do business in multiple jurisdictions will face myriad regulations dealing with billboard advertising. Organizations that rely on outdoor advertising should begin to develop alternative, targeted forms of communication, especially in jurisdictions that are taking the lead in reducing visual clutter.

For example, a Maryland federal district court recently upheld a City of Baltimore ban on billboard advertising of alcoholic beverages (Anheuser-Busch and Penn Advertising of Baltimore, Inc. v. Mayor \& City Council of Baltimore 1994). The court accepted the city's reasoning that billboards lead to the consumption of alcohol by minors without hearing any empirical evidence. This decision has been widely criticized (cf. Davis 1994) and will undoubtedly be appealed, but it illustrates the acerbic view of billboards held by many people.

\section{Direct Marketing}

Similarly, the private intrusiveness of direct marketing has made it a target of regulations aimed at diminishing market-

\footnotetext{
12The president of one firm that operates numerous billboards declared that he was already diversifying his business in anticipation of the day when outdoor advertising is banned or severely restricted (Shaw and Pearson 1994).
} 
ing efforts that are thought to be too aggressive or generally bothersome. Few first amendment challenges to direct mail statutes have been raised to date; however, this area is likely to parallel the progress observed relative to billboards and signs. ${ }^{13}$ Once legislators and regulators determine how to limit direct marketing efforts without infringing on noncommercial speech, Central Hudson provides broad discretionary power for severely reducing the variety and effectiveness of direct marketing. Regulations in this area will be particularly complex for marketers to anticipate because of the overlapping interests of several federal agencies, including the Federal Trade Commission, Federal Communications Commission, and the U.S. Postal Service.

Regulations will most likely be aimed at restricting mass mailings or randomly generated telephone contacts that are not based on the identification of high-potential prospects. To minimize the likelihood of regulations that qualify under the First Amendment, organizations that employ direct mail must secure appropriate mailing lists. Mail campaigns aimed at persons who meet exacting market profile criteria are likely to provoke the least resistance, because such mailings will yield the fewest formal complaints.

A similar admonition is relevant regarding unsolicited telephone selling. Because the phone lines that telemarketers use for commercial messages are paid for by consumers, their demands for restrictions are likely to be supported, at least until technology such as call-blocking is widely available (Cain 1994, p. 665).

\section{Personal Selling}

The activities of salespeople, although targeted at qualified prospects, have been affected by first amendment rulings. The cases related to the promotional efforts of attorneys can be conceptually extended to other salesperson-prospect situations. To date, attorneys are generally permitted to describe their expertise, but they cannot personally approach individuals who are plainly in need of legal assistance. The Court has reasoned that attorneys possess superior knowledge regarding the imminent legal dilemma and therefore might overstate the problem to gain business. Moreover, such consumers may be involved in emotionally charged situations that could interfere with their making sound decisions about retaining legal counsel The consumer is thus protected from being placed at a disadvantage by unscrupulous attorneys.

Other situations exist where the seller's knowledge exceeds that of the prospect relative to the offering in question. The potential for encroachment through regulation is considerable, particularly because the Court is more likely to allow regulations in situations where the commercial speech cannot be easily monitored by others. Thus, salesperson conduct is susceptible to regulation, because most salesperson-client interactions cannot be observed by third parties.

The current emphasis on ethical behavior by salespeople must be stressed by organizations in all industries so that external regulations are not imposed (Schneider and Johnson

\footnotetext{
13In Moser v. FCC (1993), a federal district court in Oregon outlawed a federal statute that allowed businesses to solicit customers over the phone only if they employed live operators (no computer dialing/messages). An appeal will probably be filed by the FCC.
}

1992), and the claims of salespeople should be factually correct and deal with issues that can be substantiated. Claims that are not verifiable, especially if they are common in industries or markets where sellers are obviously more knowledgeable than buyers, could lead to localized attempts at regulating salesperson speech to protect customers.

\section{Television Advertising}

The pervasive impact of television advertising has resulted in a number of regulations that prompted first amendment objections. Certain products (e.g., cigarettes, distilled spirits) are precluded from being advertised on television. The arguments here center on protecting certain vulnerable segments, generally children, from repeated exposure to product advertisements if they are deemed to be incapable of assessing a product's utility. Future regulations of televised advertising are likely to focus on certain product classes, with further emphasis on restricting ads for additional products during certain time segments. ${ }^{14}$

\section{Summary}

After reestablishing protection of commercial speech under the First Amendment during the late 1970s, the U.S. Supreme Court has once again decided to limit this protection. The Central Hudson (1980) decision provided a fourpart test that has been used to restrict both the content and method of commercial communication. The Posadas (1986) extension of Central Hudson supplies additional reasoning to limit commercial speech even further.

Most first amendment commercial speech cases deal with efforts to constrain decisions regarding the type of advertising medium, with ad content occasionally being considered. At present, the Court is moving in the direction of diminishing the rights of the seller-advertiser. A continuation of this trend will affect all aspects of the promotional mix, leading Kozinski and Banner ${ }^{15}$ (1990, p. 653) to the following conclusion:

\begin{abstract}
...the commercial speech doctrine...is not cost free. It gives a government a powerful weapon to suppress or control speech by classifying it as merely commercial. If you think carefully enough, you can find a commercial aspect to almost any first amendment case. Today's protected expression may become tomorrow's commercial speech.
\end{abstract}

\section{REFERENCES}

Adolph Coors Company v. Bentsen (1993), 2 F.2d 355 (10th Cir.); 944 F.2d 1543 (10th Cir. 1991).

Amateur Sports Act (1978), United States Code, v. 36, $\$ 380$.

Anheuser-Busch, Inc. and Penn Advertising of Baltimore, Inc. $v$. Mayor \& City Council of Baltimore (1994), Civ. Nos. HAR 94-117, HAR 94-145, slip op., 1994 U.S.Dist.Lexis 5130 (March 28, D. My.).

Bates v. State Bar of Arizona (1977), 433 U.S. 350, 97 S.Ct. 2691.

${ }^{14}$ Highly targeted communications aimed at supposedly vulnerable segments have come under attack, for example, PowerMaster, a high-alcohol malt liquor aimed at blacks (cf. Clark 1991).

${ }^{15} \mathrm{Kozinski}$ is a judge on the U.S. Court of Appeals, Ninth Circuit. His dissenting opinion in International Olympic Committee v. San Francisco Arts \& Athletics, Inc. (1986) is at odds with SFAA v. USOC (1987). 
Bigelow v. Virginia (1975), 421 U.S. 809, 95 S.Ct. 2222.

Blim, John M (1994), "Free Speech and Health Claims Under the Nutrition Labeling and Education Act of 1990: Applying a Rehabilitated Central Hudson Test for Commercial Speech," Northwestern University Law Review, 88 (Winter), 733-68.

Board of Trustees of the State University of New York v. Fox (1989), 492 U.S. 469, 109 S.Ct. 3028.

Bolger v. Youngs Drug Products Corp. (1983), 463 U.S. 60, 103 S.Ct. 2875.

Boos v. Barry (1988), 485 U.S. 312, 108 S.Ct. 1157.

Breard v. Alexandria (1951), 341 U.S. 622, 71 S.Ct. 920.

Cain, Rita Marie (1994), "Call Up Someone and Just Say 'Buy'Telemarketing and the Regulatory Environment," American Business Law Journal, 31 (February), 641-98.

Calfee, John E. and Janis K. Pappalardo (1991), "Public Policy Issues in Health Claims for Foods," Journal of Public Policy \& Marketing, 10 (Spring), 33-53.

Cantwell v. Connecticut (1940), 318 U.S. 413, 63 S.Ct. 669.

Carey, Governor of New York v. Population Services International (1977), 431 U.S. 678, 97 S.Ct. 2010.

Caywood, Clarke L. and Ivan L. Preston (1989), "The Continuing Debate on Political Advertising: Toward a Jeopardy Theory of Political Advertising as Regulated Speech," Journal of Public Policy \& Marketing, 8, 204-26.

Central Hudson Gas \& Electric Corp. v. Public Service Commission (1980), 447 U.S. 557, 100 S.Ct. 2343.

City of Cincinnati v. Discovery Network, Inc. (1993), 1993 U.S. Lexis 2401, 113 S.Ct. 1505.

City of Ladue v. Gilleo (1994), No. 92-1856, slip op., 1994 U.S.Lexis 4448, 62 U.S.L.W. 4477 (June 13); aff'd as modif'd, 986 F.2d 1180 (8th Cir. 1993); 774 F.Supp. 1564 (E.D. Mo 1991); 774 F.Supp. 1559 (E.D. Mo. 1991).

Clark, Charles S. (1991), "Advertising Under Attack," CQ Researcher 18 (September), 658-80.

$\rightarrow$ Cohen, Dorothy (1978), "Advertising \& the First Amendment," Journal of Marketing, 42 (July), 59-68.

Collins, Ronald K.L. and David M. Skover (1993a), "Commerce \& Communication," Texas Law Review, 71 (March), 697-746.

and (1993b), "The Psychology of First Amendment Scholarship: A Reply," Texas Law Review, 71 (March), 819-32.

Cutler, Bob D. and Darrel D. Muehling (1989), "Advocacy Advertising and the Boundaries of Commercial Speech," Journal of Advertising, 18 (September), 40-50.

and (1991), "Another Look at Advocacy Advertising and the Boundaries of Commercial Speech," Journal of Advertising, 20 (December), 49-52.

Davis, Ralph D. (1994), "New Prohibitionism on Trial: Judicial Approval of Baltimore's Ad Ban Should Be Reversed," Legal Backgrounder, 9 (April 29).

Dowdell, Stephen and Jonna Crispens (1991), "Industry Behind New Label Rules," Supermarket News (November 11), 1.

Edenfield v. Fane (1993), 1993 U.S. Lexis 2985, 113 S.Ct. 1792; 945 F.2d 1514 (1991 11th Cir.).

ES Development, Inc. v. RWM Enterprises, Inc. (1991), 939 F.2d 547 (8th Cir.); cert. denied, 112 S.Ct. 1176 (1992).

Estlund, Cynthia L. (1990), "Speech on Matters of Public Concern: The Perils of an Emerging First Amendment Category," George Washington Law Review, 59 (November), 1-55.

First National Bank of Boston v. Bellotti, Attorney General of Massachusetts (1977), 435 U.S. 765, 98 S.Ct. 1407.

Friedman v. Rogers (1979), 440 U.S. 1, 99 S.Ct. 887.

Garrison, Michael J. (1991), "The New 'Improved' Commercial Speech Doctrine: Constitutional Protection for the Dissemination of Commercial Information in the Renquist Era," presented to the American Business Law Association.
Gaudiya Vaishnava Society v. City and County of San Francisco (1991), 952 F.2d 1059 (9th Cir.); cert. denied, 112 S.Ct. 1951 (1992).

Hays County Guardian v. Supple (1992), 969 F.2d 111 (5th Cir.); cert. denied, 113 S.Ct. 1067 (1993).

Husni, Samir (1991), "Straight Talk," Folio: The Magazine for Magazine Management (December 1), 2.

Ibanez v. Florida Department of Business and Professional Regulation, Board of Accountancy (1994), No. 93-639, slip op., 1994 U.S.Lexis 4443, 62 U.S.L.W. 4503 (June 13).

In Re Primus (1978) 436 U.S. 412, 98 S.Ct. 1893.

In Re R.J. Reynolds Tobacco Company, Inc. (1990), Federal Trade Commission, Docket No. 9206.

In Re R.M.J. (1982), 455 U.S. 191, 102 S.Ct. 929.

International Olympic Committee v. San Francisco Arts \& Athletics, Inc. (1986), 789 F.2d 1319 (9th Cir.).

Jamison v. Texas (1943), 318 U.S. 413, 63 S.Ct. 669.

Kozinski, Alex and Stuart Banner (1990), "Who's Afraid of Commercial Speech?” Virginia Law Review, 76 (May), 627-53.

and - (1993), "The Anti-History and Pre-History of Commercial Speech," Texas Law Review, 71 (March), 747-75.

Lanham Act (1988), United States Code, v. 15, \$42-43, $\$ 1051-1053$.

Linmark Associates, Inc. v. Township of Willingboro (1977), 431 U.S. 85, 97 S.Ct. 1614.

Lovell v. Griffin (1938), 303 U.S. 444, 58 S.Ct. 666.

Mandel, Richard P. (1994), "Regulation of Commercial Speech: Did the 1993 Supreme Court Decisions Clarify the Scope of First Amendment Protection?" Journal of Public Policy \& Marketing, 13 (Spring), 159-62.

Martin v. Struthers (1943), 319 U.S. 141, 63 S.Ct. 862.

$\rightarrow$ McGowan, David F. (1990), "A Critical Analysis of Commercial Speech," California Law Review, 78 (March), 359-448.

Messer v. City of Douglasville (1992), 975 F.2d 1505 (11th Cir.), cert. denied, 113 S.Ct. 2395 (1993).

Metromedia, Inc. v. San Diego (1981), 453 U.S. 490, 101 S.Ct. 2882.

Middleton, Kent R. (1991), "Advocacy Advertising, The First Amendment, and Competitive Advantage," Journal of Advertising, 20 (June), 77-81.

Moser v. Federal Communications Commission (1993), 826 F.Supp. 360 (D. Ore.).

Murdock v. Pennsylvania (1943), 319 U.S. 105, 63 S.Ct. 870.

Nesgos, Nicholas (1988), "Pacific Gas and Electric Co. v. Public Utilities Commission: The Right to Hear in Corporate Negative and Affirmative Speech," Cornell Law Review, 73 (July), $1080-1100$.

New York Times v. Sullivan (1964), 376 U.S. 254, 84 S.Ct. 710.

Nutrition Labeling and Education Act (1990), United States Code, v. 21, $\$ 343$ (1988 and Supplement III, 1991).

Ohralik v. Ohio State Bar Association (1978), 436 U.S. 447, 98 S.Ct. 1912.

Peel v. Attorney Registration and Disciplinary Commission of Illinois (1990), 496 U.S. 91, 110 S.Ct. 2281.

Petty, Ross (1993), "Advertising \& the First Amendment: A Practical Test for Distinguishing Commercial Speech from FullyProtected Speech," Journal of Public Policy \& Marketing, 12 (Fall), 170-77.

Posadas de Puerto Rico Associates v. Tourism Company of Puerto Rico (1986), 478 U.S. 328, 106 S.Ct. 2968.

R.A.V. v. City of St. Paul (1992), 112 S.Ct. 2538, 120 L.Ed.2d 305.

Radner, Jennifer L. (1993), "Phone, Fax, and Frustration: Electronic Commercial Speech and Nuisance," Emory Law Journal, 42 (Winter), 359-417.

Redish, M.H. (1990), "Product Health Claims and the First Amendment: Scientific Expression and the Twilight Zone of 
Commercial Speech," Vanderbilt Law Review, 43 (October), 1433-1460.

San Francisco Arts \& Athletics, Inc. v. United States Olympic Committee (1987), 483 U.S. 522, 1076 S.Ct. 2971.

Schneider v. State (1939), 308 U.S. 147, 60 S.Ct. 146.

Schneider, Kenneth C. and James C. Johnson (1992), "Professionalism and Ethical Standards Among Salespeople in a Deregulated Environment: A Case Study of the Trucking Industry," Journal of Personal Selling \& Sales Management, 12 (Winter), $33-44$.

Shapero v. Kentucky Bar Association (1988), 486 U.S. 466, 108 S.Ct. 1916.

Shaw, Sandy and Durk Pearson (1994), "Speakeasies in a New Age of Prohibition," Legal Backgrounder, 9 (April 22).
Smolla, Rodney A. (1993), "Information, Imagery, and the First Amendment: A Case for Expansive Protection of Commercial Speech," Texas Law Review, 71 (March),777-804.

Thomas v. Collins (1945), 323 U.S. 516, 65 S.Ct. 315.

United States and Federal Communications Commission v. Edge Broadcasting Co. (1993), 1993 U.S. Lexis 4402, 113 S.Ct. 2696.

Valentine v. Chrestensen (1942), 316 U.S. 52, 62 S.Ct. 920.

Virginia State Board of Pharmacy v. Virginia Citizens' Consumer Council, Inc. (1976), 425 U.S. 748, 96 S.Ct. 1817.

Wade, Betsy (1992), "Practical Traveler: Where to Find No-Frills Facts," New York Times (January 19), 5.3.

Waldholz, Michael (1992), “Johnson \& Johnson's Retin-A Can Ease Problem of Liver Spots,” Wall Street Journal (February 6), B7.

Public Publication: Journal of Marketin

Publication No. 0022-2429

. Filing Date: Oct. 1, 1994

5. Issue Frequency: Quarterly

6. Annual Subscription Price: $\$ 70$

6. Annual Subscription Price: $\$ 70$ Complete Mailing Address of Known Office of Publication: 250 South Wacker Dr, Suite 200, Complete Mailing Address

8. Chicago, IL 60606-5819 of Kno Complete Mailing Address of the Headquarters or General Business Offices of the Publisher 250 South Wacker Dr., Suite 200, Chicago, IL 60606-5819

9. Full Names and Complete Mailing Address of Publisher, Editor, and Managing Editor Group Publisher: Hope M. Bulger, 250 South Wacker Dr., Suite 200, Chicago, IL 60606-5819, Editor: P. Rajan Varadarajan, Dept. of Marketing, College of Bus. Ad., Texas A \& M University,

Managing Editor: Francesca Van Gorp, 250 South Wacker Dr., Suite 200, Chicago, IL 60606-5819

Owner: American Marketing Association, 250 South Wacker Dr., Suite 200, Chicago, IL 60606 5819

11. Known Bondholders, Mortgagees, and Other Security Holders Owning or Holding $1 \%$ or More of Total Amount of Bonds, Mortgages, or Other Securities (If there are none, so state):

For completion by nonprofit organizations authorized to mail at special rates. The purpose, function, and nonprofit status of this organization and the exempt status for federal income tax purposes Has Not Changed D

14. Issue Date for Circulation Data Below: October, 1994-Vol. 58, No. 4

15. Extent and Nature of Circulation:

a. Total No. Copies (Net Press Run)

(1) Sales through dealers and carriers, street

vendors, and counter sales (not mailed)

2) Paid or Requested Mail Subscriptions (Include

Advertisers' Proof Copies/Exchange Copies)

Total Paid and/or Requ

d. Free Distribution by Mail (Samples, Complimentary,

and Other Free)

and Other Free)

Other Means)

f. Total Free Distribution (Sum of $15 \mathrm{~d}$ and 15e)

g. Total Distribution (Sum of $15 \mathrm{c}$ and $15 \mathrm{f}$ )

h. Copies Not Distributed

(1) Office Use, Leftovers, Spoiled
(2) Repied

(2) Return from News Agents

i. Total (Sum of $15 \mathrm{~g}, 15 \mathrm{~h}(1)$, and $15 \mathrm{~h}(2))$

Percent Paid and/or Requested Circulation

$(15 \mathrm{c} / 15 \mathrm{~g} \times 100)$

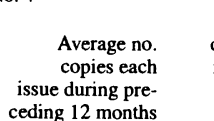

ceding 12 months

10,293

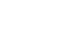

51
9,059

9,059

9,110

572

125
697

697
9,807

9,807

$\frac{613}{10,420}$

93\% paid

16. This Statement of Ownership will be printed in the January, 1995, issue of this publication

7. Signature and tille of editor, publish
Hope M. Bulger, Group Publisher.

I certify that the information furnished on this form is true and complete. I understand that anyone who

furnishes false or misleading information on this form or who omits material or information requested on the form may be subject to criminal sanctions (including fines and imprisonment) and/or civil sanctions
(including multiple damages and civil penalties).

Actual no. copies of single published nearest to 9,840 0 8,857 8,857 447 0 9,304 533

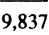

$95 \%$ paid 